\title{
Shale Hydrocarbon Development Based on Drill Cuttings \& TOC Analysis: Case Study of Brownshale Drill Cuttings of Well BS-03, Pematang Formation, Bengkalis Trough, Central Sumatra Basin
}

\author{
Aris Buntoro' ${ }^{1}$, Carolus Prasetyadi' ${ }^{2}$, Ricky Adi Wibowo ${ }^{3}$, Suranto ${ }^{1}$ \\ ${ }^{1}$ Petroleum Engineering Department, UPN “Veteran” Yogyakarta, Yogyakarta, Indonesia \\ ${ }^{2}$ Geological Engineering Department, UPN “Veteran” Yogyakarta, Yogyakarta, Indonesia \\ ${ }^{3}$ Upstream Technical Center, PT. Pertamina (Persero), Jakarta, Indonesia \\ Email: arisbuntoro@upnyk.ac.id
}

How to cite this paper: Buntoro, A., Prasetyadi, C., Wibowo, R.A. and Suranto (2020) Shale Hydrocarbon Development Based on Drill Cuttings \& TOC Analysis: Case Study of Brownshale Drill Cuttings of Well BS-03, Pematang Formation, Bengkalis Trough, Central Sumatra Basin. Open Journal of Yangtze Gas and Oil, 5, 86-101.

https://doi.org/10.4236/ojogas.2020.53008

Received: March 30, 2020

Accepted: May 11, 2020

Published: May 14, 2020

Copyright $\odot 2020$ by author(s) and Scientific Research Publishing Inc. This work is licensed under the Creative Commons Attribution International License (CC BY 4.0).

http://creativecommons.org/licenses/by/4.0/

\section{Abstract}

Brownshale is a lithology unit in the middle of the Pematang Formation consisting of brown to black shale that is deposited in the lacustrine environment. Brownshale from the results of previous studies stated as the main source rock in the Central Sumatra Basin, which is spread over several troughs, namely Balam, Aman, Rangau, Kiri, and Bengkalis Troughs, where Bengkalis Trough is the most extensive Trough. In the shale hydrocarbon prospecting analysis, Brownshale from previous researchers concluded that it had good prospects, based on several parameters including: TOC values with poor to very good quality. Brownshale formation is a type of kerogene as kerogen type of II/III, brittleness index greater than 0.48 , and rock compressive strength below 10,000 Psi. One method in the development phase of shale hydrocarbon is to determine the fracable sweetspot window using drill cuttings and TOC, because there is no core data available. Based on the results of the well $\log$ analysis of well BS-03, it is obtained information that the Brownshale formation has a thickness of 1028 feet with intercalation laminated shale/sand section, so the mineral content varies greatly. From the ternary diagram of XRD (bulk analysis) results of drill cuttings of Brownshale formation of well BS-03, it can be seen that mineral distribution of Quartz-Clay-Calcite (Q-C-C) is spread between zone 1 to zone 3, namely: Dominant Quartz Minor Clay \& Carbonate (Zone 1: Brittle Quartz Rich), Dominant Carbonate - Quartz \& Minor Clay (Zone 2: Brittle Carbonate Rich), and Quartz \& Carbonate Balance - Clay minor (Zone 3: Ductile, hard to frac). This shows that 
not all Brownshale formation intervals are easy to frac (high fracability). From the XRD result, percentage of mineral content (bulk analysis) of Brownshale drill cuttings, there is an interesting phenomenon, i.e. the presence of sillimanite and kaliophilite minerals significantly starting at a depth of $10,780 \mathrm{ft}$ and below, where both minerals have tenacity: brittle, and also from the results of the MBT analysis seen an interesting phenomenon, i.e. at a depth interval of about $10,780 \mathrm{ft}$ the value of CEC drops below $3 \mathrm{meq} / 100$ grams, and can be categorized as the brittle shale. Referring to the presence of sillimanite and kaliophilite minerals, as well as low MBT values, then at intervals of $10,780 \mathrm{ft}$ below, it can be seen that at the bottom of the depth interval as a fracable sweetspot window, and at the upper depth interval of the Brownshale formation, it is believed to be a fracture barrier.

\section{Keywords}

Shale Hydrocarbon, Mineralogy (XRD) Analysis, TOC Analysis, Fracability Model

\section{Introduction}

In recent years, conventional hydrocarbon production in the world has decreased rapidly and several countries, including the United States (USA), Canada and China, have gradually developed non-conventional hydrocarbon resources from the exploration phase to production [1]. At present, Indonesia has an immense potential for shale hydrocarbon, where the Central Sumatra Basin is the biggest potential in Indonesia, especially from the Brownshale Formation of Pematang Group. However, shale hydrocarbon development in Indonesia still little studied and poorly understood [2]. In the development of shale hydrocarbon, formation intervals with high fracability must be chosen [1], and fracability is a function of the brittleness index, which can be calculated from Young's Modulus and Poisson's ratio [3].

In producing shale hydrocarbon formations with very low permeability, information about rock mineralogy is needed as a basis for determining formation intervals with high fracability [4], so a mineralogical and TOC analysis is needed to model prospect intervals using drill cuttings data.

Thus, research related to non-conventional hydrocarbon resources, with case study of Brownshale formations, Pematang Group, Central Sumatra Basin can be used as a model for the development of shale hydrocarbon.

\section{Methodology}

Bengkalis Trough is located in three districts, i.e. Siak Sri Indrapura Regency, Bengkalis Regency, and Pelalawan Regency, Riau Province (Figure 1). At present Bengkalis Trough area is managed by 2 oil company operators, namely Malacca Strait EMP Group and CPP Block BOB PT. Bumi Siak Pusako-Pertamina Hulu, who each gave permission and contributed to carry out this research. 


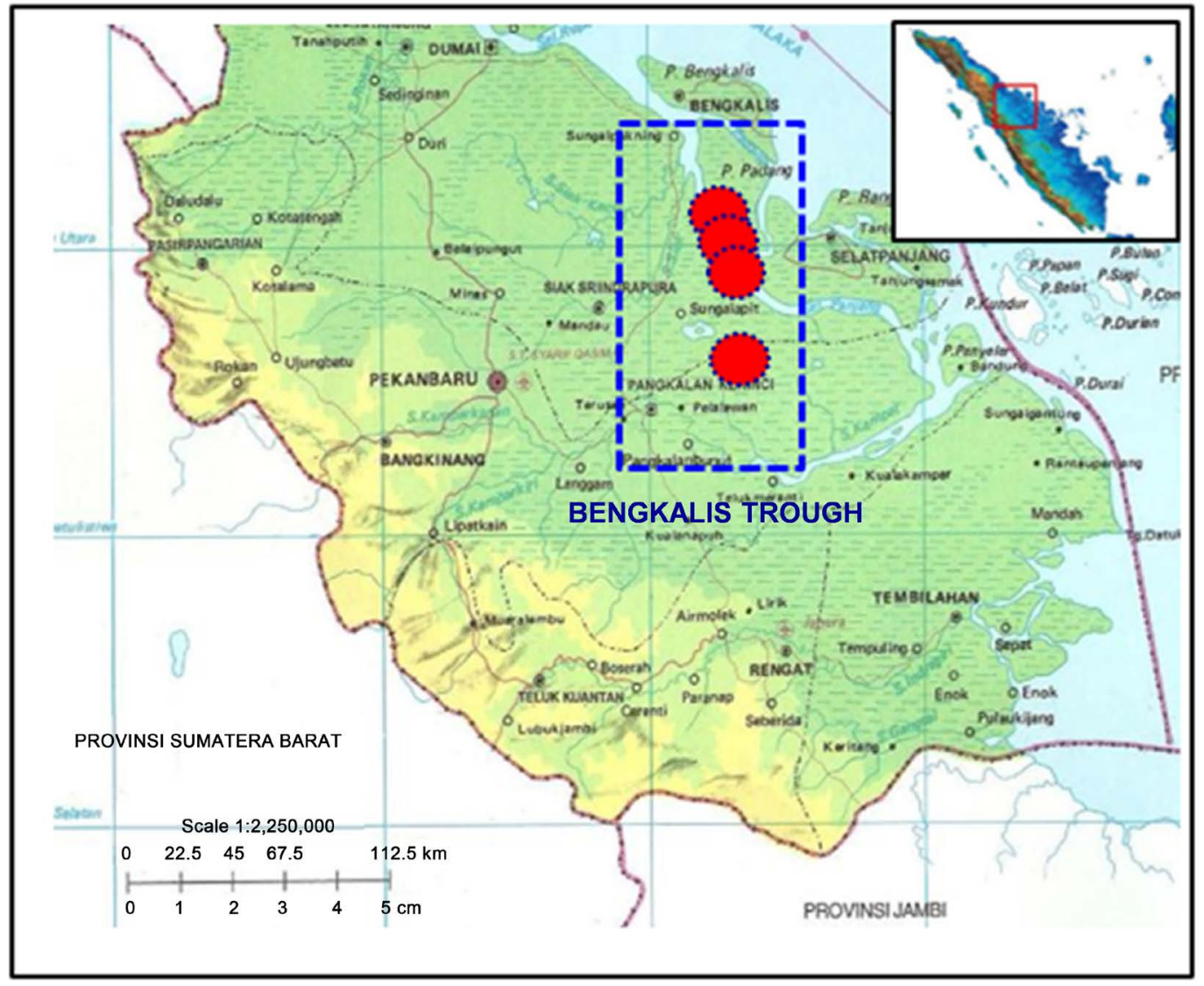

Well Location (Well BS-02, BS-03, KCBS-1 and KRBS-03)

Figure 1. The location of study area (Bengkalis Trough).

Figure 2 shows the integration of mineralogy (XRD) \& TOC analysis from drill cuttings data to build a fracability model. This paper focuses on the Brownshale formation, Pematang Group, Bengkalis Trough by integrating the results of the proposed mineralogy (XRD) and TOC analysis in a workflow, through several stages to obtain a sweetspot fracable window.

\section{Literature Review}

\subsection{Stratigraphy of Central Sumatra Basin}

The Pematang Group is the main source rock of hydrocarbon in the Central Sumatra Basin and is the oldest sedimentary layer in Paleogene (Figure 3). Syn-rift sediment the formation of Pematang Group is deposited unconformity in the half-graben.

The discovery of fossils of ostracods, freshwater gastropods, spores, pollen, dinoflagellates, algae and fern debris on core rock samples and drill cuttings powder in all major troughs and the absence of foraminifera provides an indication of the non-marine depositional environment in humid and tropical environments [5]. Based on its lithological characteristics, the Pematang Group is divided into three formations, namely: Lower Red Bed Formation, Brown Shale Formation and Upper Red Bed Formation. 


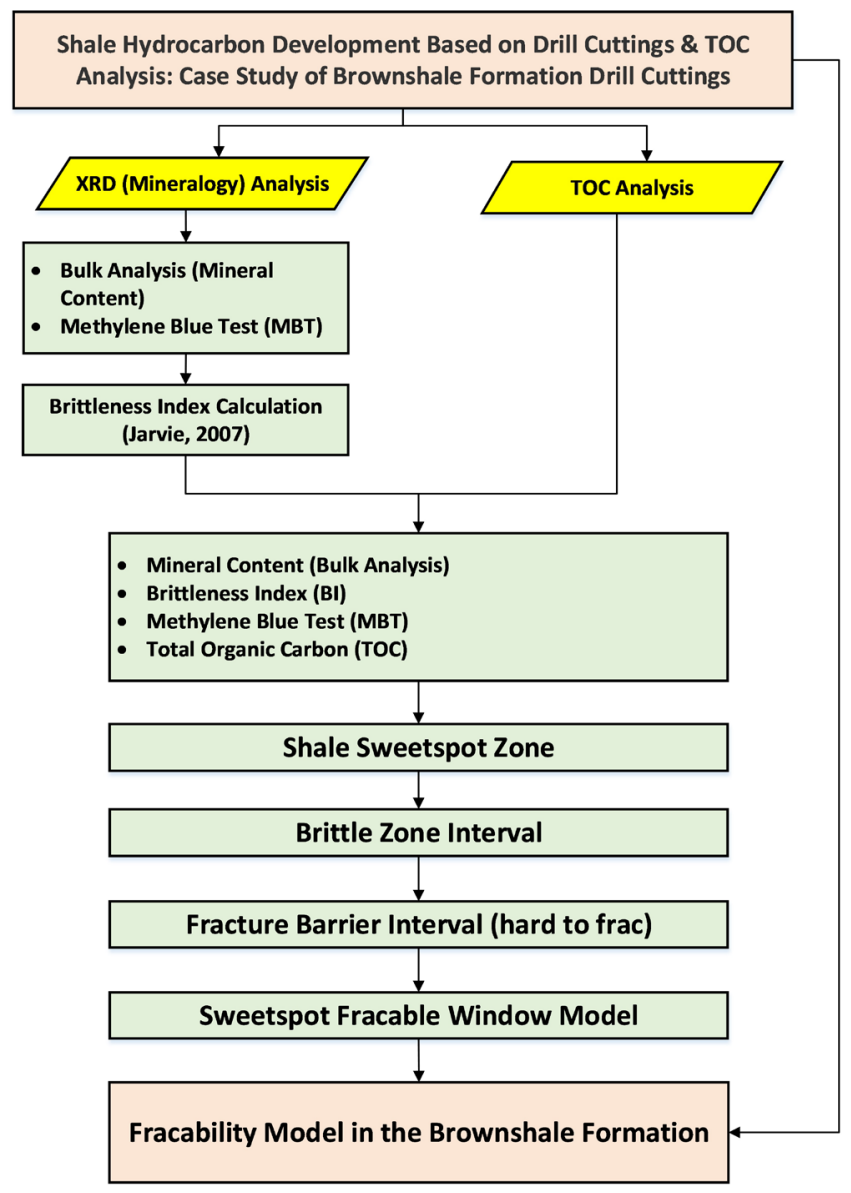

Figure 2. The integration of mineralogy (XRD) \& TOC analysis from drill cuttings data to build fracability model of Brownshale formation in Well BS-03.

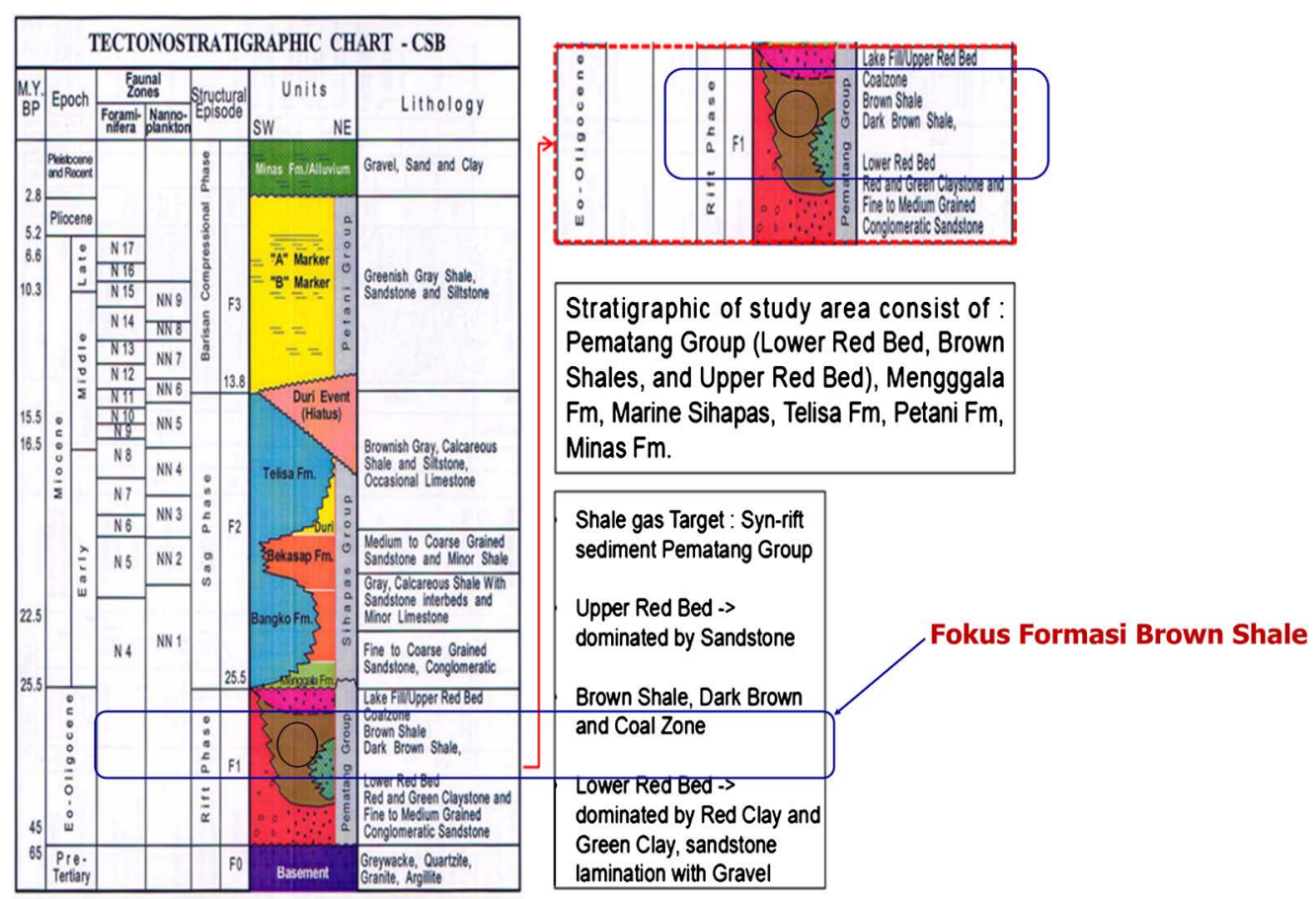

Figure 3. Stratigraphy of Central Sumatra Basin (Heidrick and Aulia, 1993). 
1) Lower Red Bed Formation

This formation consists of claystone, siltstone, arctic sandstones and a few conglomerates deposited in the environment of alluvial plains and in fluvial environments. The lower part of this formation in several deep basins can reach a thickness of 3000 meters. Sandstones in this formation have poor quality as a reservoir because they are still very close to the source and have poor sorting.

2) Brown Shale Formation

As the name implies, this formation consists of brown shale and deposited on the Lower Red Bed Formation with a lacustrine depositional environment. Shale in this formation is rich in organic matter, has a fairly good laminate which indicates that the shale is deposited in fairly calm water conditions. This shale is rich in organic matter so this formation is a hydrocarbon source rock for the reservoir located in the Central Sumatra Basin. This formation is also composed of delta and turbidite fan deposits. Turbidite deposits formed by granular flow mechanisms have been used as exploration targets which generally have stratigraphic trap types.

3) Upper Red Bed Formation

This formation is deposited in the final stage of $\mathrm{F} 1$ phase tectonics. Increasing the speed of sedimentation and clastic supply causes the basin to become full and the environment to become fluvial and alluvial. The lithology of this formation is in the form of red-green sandstones, conglomerates and claystones. Sandstone in this formation is an exploration target.

\subsection{XRD Analysis}

X-Ray Diffraction (XRD) analysis is conducted to identify the types of minerals contained in each rock sample using the bulk analysis method. In bulk analysis, shootings are carried out with shooting angles of $3^{\circ}$ up to $90^{\circ}$. After getting the results of shooting or running samples using the XRD tool, the results of the analysis are presented in the form of peaks from the XRD reading chart and the types of minerals present in the sample can be determined based on determinant peaks [6].

The type of mineral that has been identified is carried out a semi-quantification analysis to determine the percent of minerals in each depth sample. The mineral percentage is calculated using Equation (1).

$$
\text { Percentage of minerals } A=\frac{I_{A}}{\left(I_{A}+I_{B}+\cdots+I_{n}\right)} \times 100 \%
$$

where $I$ is the determinant peak intensity of one type of mineral, while $A, B, \cdots n$ are the types of minerals identified in each sample.

\section{Brittleness Analysis from the XRD Laboratory Test}

Brittleness is the measurement of stored energy before failure, and is function of rock strength, lithology, texture, effective stress, temperature, fluid type, diagenesis, and TOC. Brittleness Index (BI) is the most widely used parameter for the quantification of rock brittleness [7]. 
In recent years, brittleness has been used as a descriptor in selecting formation zone intervals for hydraulic fracking ([8] [9] [10]). Therefore, brittleness is one of the most important rock-mechanical properties, and is used in determining prospecting of shale hydrocarbon.

Brittleness index based on the results of XRD analysis can be calculated using a formula from Equation (2) [8] as follows:

$$
B I_{(\text {Jarvie, 2007) }}=W_{q t z} / W_{t}
$$

where $W_{q t z}=$ weight of quartz; and $W_{t}=$ total mineral weight

\subsection{MBT Analysis}

Methylene Blue Test (MBT) is used to determine the ability of clay to bind the cation of a solution, namely by using methylene blue to measure the total cation exchange capacity of the clay, where the cation exchange depends on the type and crystallinity of the mineral, the $\mathrm{pH}$ of the solution, the type of cation exchanged, and concentration of mineral content contained in clay.

The cation exchange capacity (CEC) is based on the sequence of ionic bond strengths as follows:

$$
\mathrm{Li}^{+}<\mathrm{Na}^{+}<\mathrm{H}^{+}<\mathrm{K}^{+}<\mathrm{NH}^{4+}<\mathrm{Mg}^{3+}<\mathrm{Ca}^{2+}<\mathrm{Al}^{3+}
$$

The largest cation exchange value is owned by allogenic minerals (fragments of source rock), while the smallest is owned by authogenic (chemical processes). The cation exchange capacity of several types of clay minerals is shown in Table 1.

\subsection{Total Organic Carbon (TOC) Analysis}

Determination of the total original organic carbon $\left(\mathrm{TOC}_{\mathrm{o}}\right.$ ) from source rock provides a quantitative means for estimating the total volume of hydrocarbons that can be produced depending on the type of kerogen. Broadly explored areas generally have mature source rocks, so it is not easy to determine the original values. Consideration of the TOC component helps in understanding how to restore highly mature TOC to $\mathrm{TOC}_{\mathrm{o}}[8]$.

Rocks that contain a lot of carbon are called high source rocks containing carbon elements (high TOC). The requirements as a source rock, which contains high organic content and has a type of kerogen that has the potential to produce hydrocarbons and has reached a certain maturity, so that it can produce hydrocarbons. Peters and Cassa (1994) divide into 5 types of source rock, as shown in Table 2.

Table 1. Typical CEC values for various clay and sand [11].

\begin{tabular}{cc}
\hline CLAY MINERAL & CEC RANGE OF VALUES \\
\hline Smectite & 80 to $120 \mathrm{meq} / 100 \mathrm{~g}$ \\
Illite & 10 to $40 \mathrm{meq} / 100 \mathrm{~g}$ \\
Kaolinitee & 3 to $15 \mathrm{meq} / 100 \mathrm{~g}$ \\
Chlorite & 10 to $40 \mathrm{meq} / 100 \mathrm{~g}$ \\
Sand & $<0.5 \mathrm{meq} / 100 \mathrm{~g}$ \\
\hline
\end{tabular}


Table 2. Type of source rock [12].

\begin{tabular}{cc}
\hline Type of Source Rock & TOC Content (wt\%) \\
\hline Poor Source Rock & $0-0.5$ \\
Fair Source Rock & $0.5-1$ \\
Good Source Rock & $1-2$ \\
Very Good Source Rock & $2-4$ \\
Excellent Source Rock & $>4$ \\
\hline
\end{tabular}

\subsection{Basic Criteria for the Development of Shale Hydrocarbon}

Shale hydrocarbon parameters that can be produced commercially include several criteria, as follows [13]:

1) TOC: $>2 \%$

2) Shale thickness: $>100 \mathrm{ft}$

3) Moderate clay content: $<40 \%$

4) Brittle Index shale: $>0.48$

5) Brittle shale (fracability): i.e. low Poisson's ratio \& high Modulus Young

\section{Result and Discussion}

\subsection{Mineral Analysis with XRD \& MBT Laboratory Test Using Drill Cuttings Data}

In the development of shale hydrocarbon in the Brownshale formation at Bengkalis Trough based on XRD (bulk) and MBT analysis from drill cuttings data, using the drill cuttings of well that penetrated the Pematang formation, namely well BS-02, well BS-03, well KCBS-01, and well KRBS-03. Figure 4 shows the correlation of well logs from wells BS-02, BS-03, KCBS-01 and KRBS-03. Based on the correlation of the four wells, only well BS-03 penetrated the Brownshale formation, which was confirmed by composite log data such as seen in Figure 4, so the mineralogy (XRD) and MBT analysis to determine the fracability model of Brownshale formation only used the drill cuttings of well BS-03 data with depth interval of 9860 to $11,642 \mathrm{ft}$ which were divided into $10 \mathrm{ftMD}$ intervals of 46 samples. Dominant peaks in the graph are calculated basal spacing values (d) to be analyzed for mineral types by matching these values with the mineral standards in the "Handbook of Mineralogy".

The results of the XRD analysis (bulk) of the Brownshale Formation drill cuttings sample in well BS-03, which include percent of Quartz, Clay and Calcite content versus depth, are shown in Figure 5.

From the results of the bulk analysis at each depth interval, it is obtained the main mineral content percent (Quartz, Clay, and Calcite), so that by using equation 2 a Brittleness index can be determined, as shown in Figure 6. Shale hydrocarbon parameters that can be produced commercially one the criteria is brittleness index $>0.48$ [13], and in Figure 5 shows that the entire depth interval of the Brittleness index value is greater than 0.48 , so it can be concluded that the 
Brownshale formation from the results of mineralogical analysis is brittle.

From the results of the bulk analysis, in addition to the main mineral content, there is an interesting phenomenon, namely the presence of minerals sillimanite and kaliophilite significantly starting at a depth of $10,780 \mathrm{ft}$ towards the bottom of the Brownshale formation, where both minerals have tenacity: brittle [6]. Figure 7 shows the presence of the sillimanite and kaliophilite minerals.

In determining the prospect interval (sweetspot fracable window) of shale

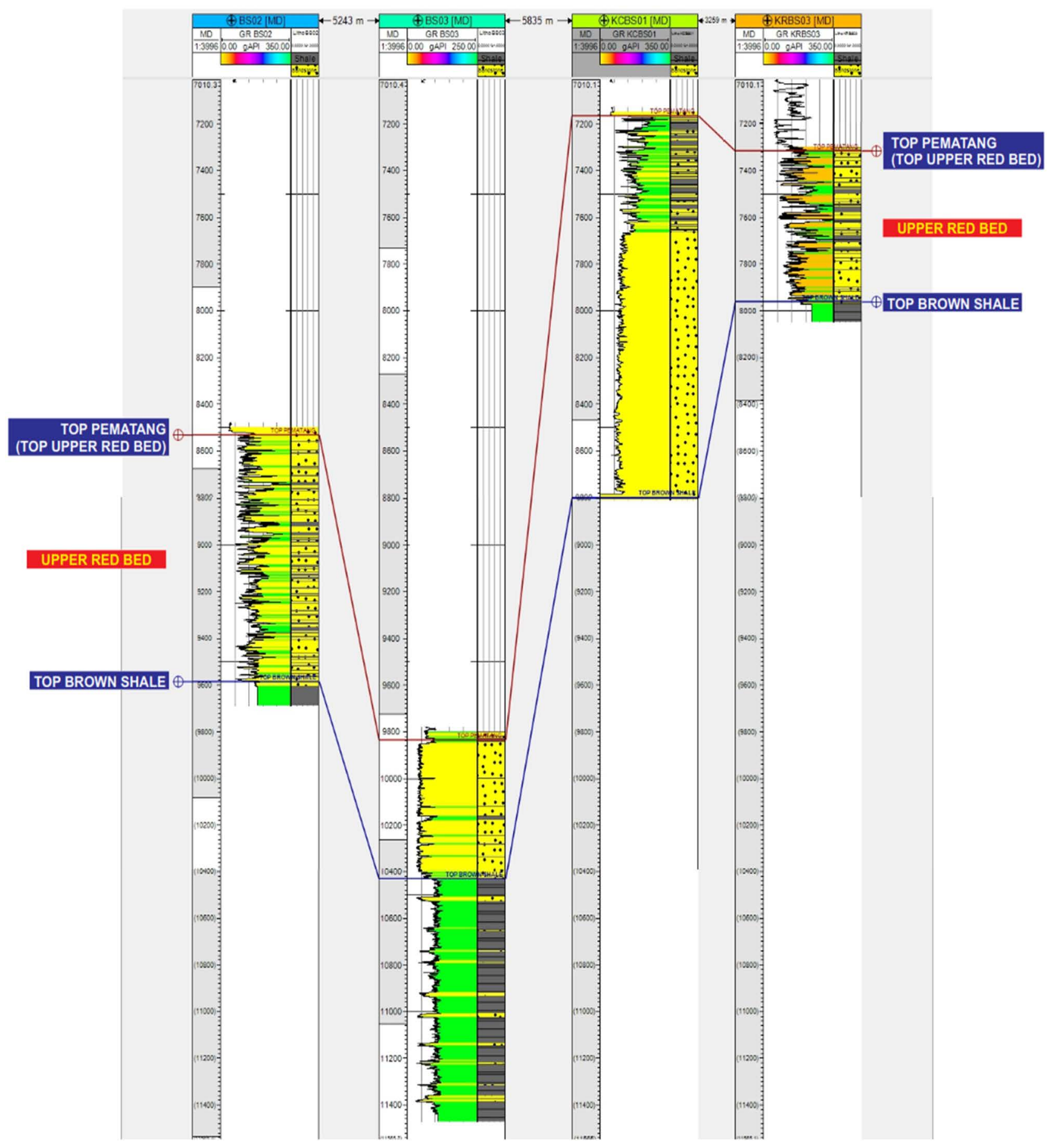

Figure 4. Correlation of well logs from wells BS-02, BS-03, KCBS-01 and KRBS-03. 


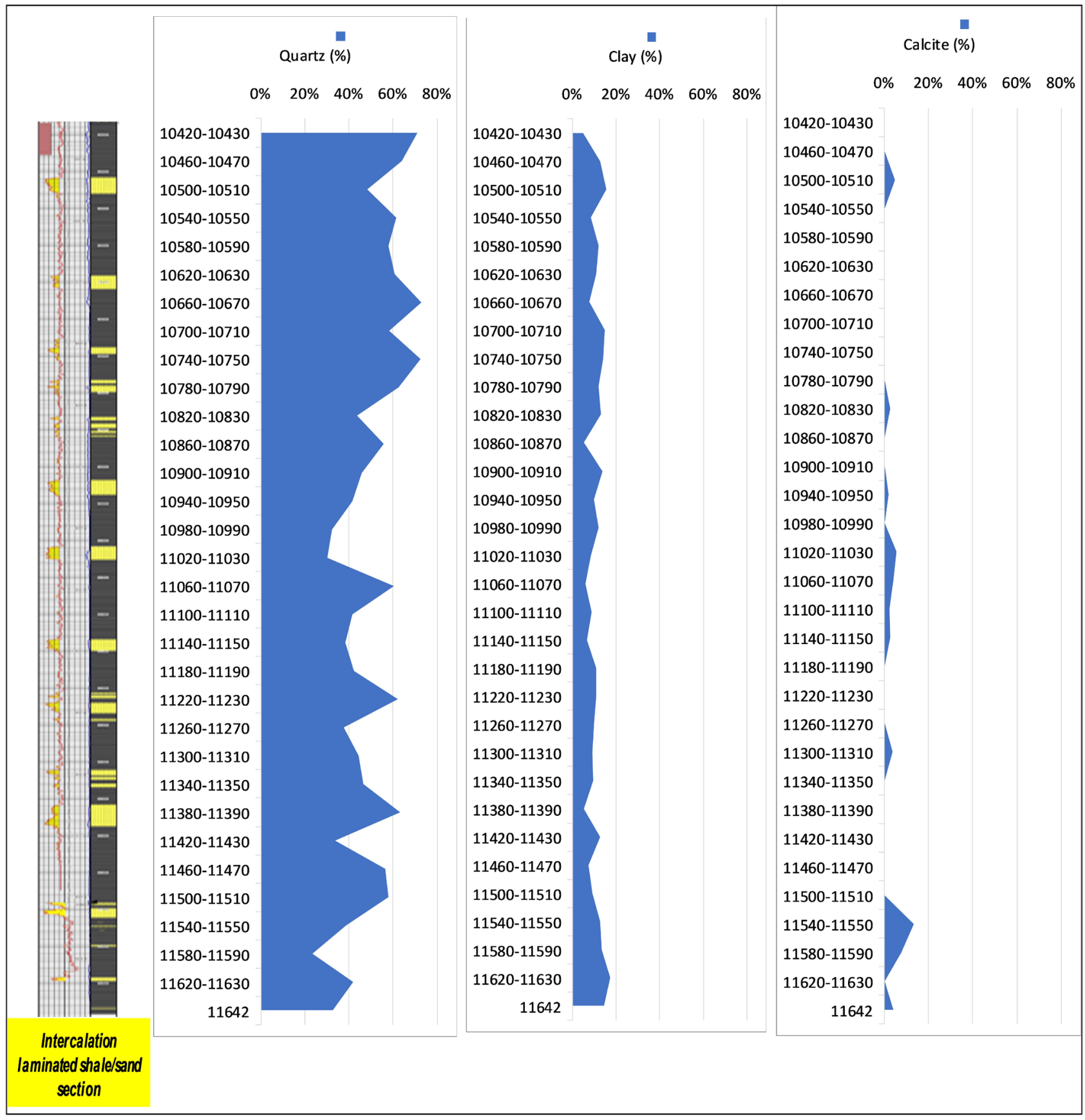

Figure 5. Quartz-Clay-Calcite (Q-C-C) Content (\%) vs. Depth interval of Brownshale Drillcuttings of Well BS-03.

hydrocarbon, not only the brittleness index is calculated from the XRD (bulk) analysis, but also from the results of the MBT analysis. From the results of the MBT analysis can be seen an interesting phenomenon, namely at a depth interval of about 10,780 MDft the value drops below $3 \mathrm{meq} / 100$ grams, including the brittle category [14]. Figure 8 shows the results of the MBT analysis of drill cuttings of well BS-03.

Referring to the presence of sillimanite and kaliophilite minerals, as well as low MBT values, at a depth interval of $10,780 \mathrm{ft} \mathrm{MD}$ to the bottom depth interval it is believed to be a hydraulic fracking candidate. MBT values, at these intervals 


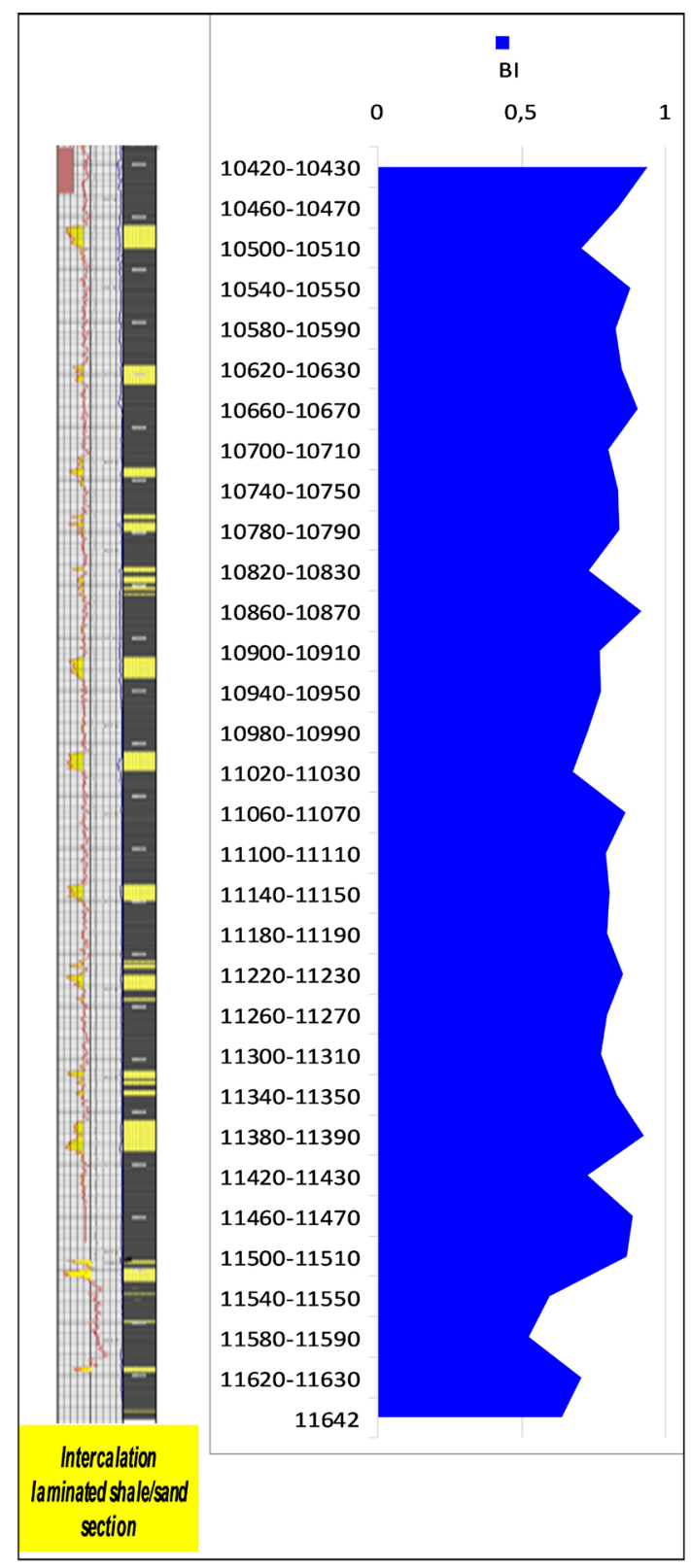

Figure 6. Brittleness Index from XRD analysis results [8] vs. Depth interval of Brownshale Drill cuttings of Well BS-03.

generally also low values, including the brittle category [14].

From other calculation methods, it can also be determined the nature of brittle rocks using ternary diagrams based on their mineral content, namely quartz, clay and calcite. Based on the XRD analysis (bulk) results of mineral compositions from the drill cuttings, a plot can be made on the ternary diagram. The ternary diagram plot of the XRD analysis (bulk) results of drill cuttings sample of the Brownshale formation of Well BS-03 is shown in Figure 9.

From the Figure 9 it can be seen that the XRD results (bulk analysis) from the Brownshale drill cuttings are distributed between zone 1 to zone 3 , where the spread of zone 3 is more dominant. This can be discussed, as follows: 


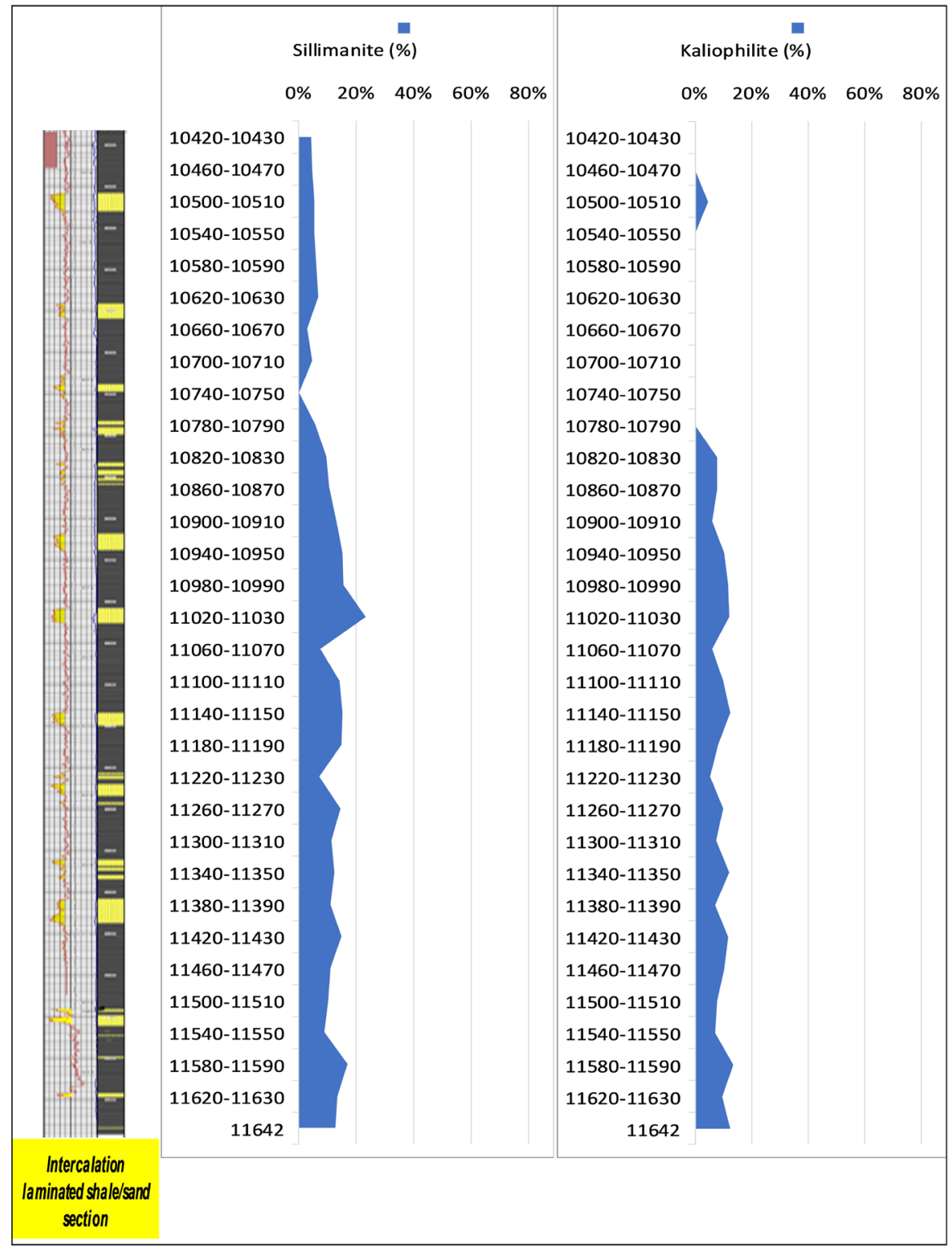

Figure 7. Silimanite \& Kaliophilite Minerals Content (\%) vs. Depth interval of Brownshale Drill cuttings of Well BS-03.

- Zone 1: Quartz dominant - Clay \& Carbonate minor (Brittle quartz rich)

- Zone 2: Carbonate dominant - Quartz \& Clay minor (Brittle carbonate rich)

- Zone 3: Quartz \& Carbonate Balance - Clay minor (Ductile, hard to frac)

\subsection{TOC Analysis Using Drill Cuttings Data}

The results of the TOC analysis of the Brownshale drill cuttings of well BS-03 were performed laboratory tests using 10 drill cuttings samples shown in Table 3.

\subsection{Integration of Mineralogy, MBT and TOC Analysis Result for Hydrocarbon Shale Development}

In the development of shale hydrocarbon in the Brownshale formation from the results of mineralogy (XRD), MBT and TOC analysis of the drill cuttings sample 


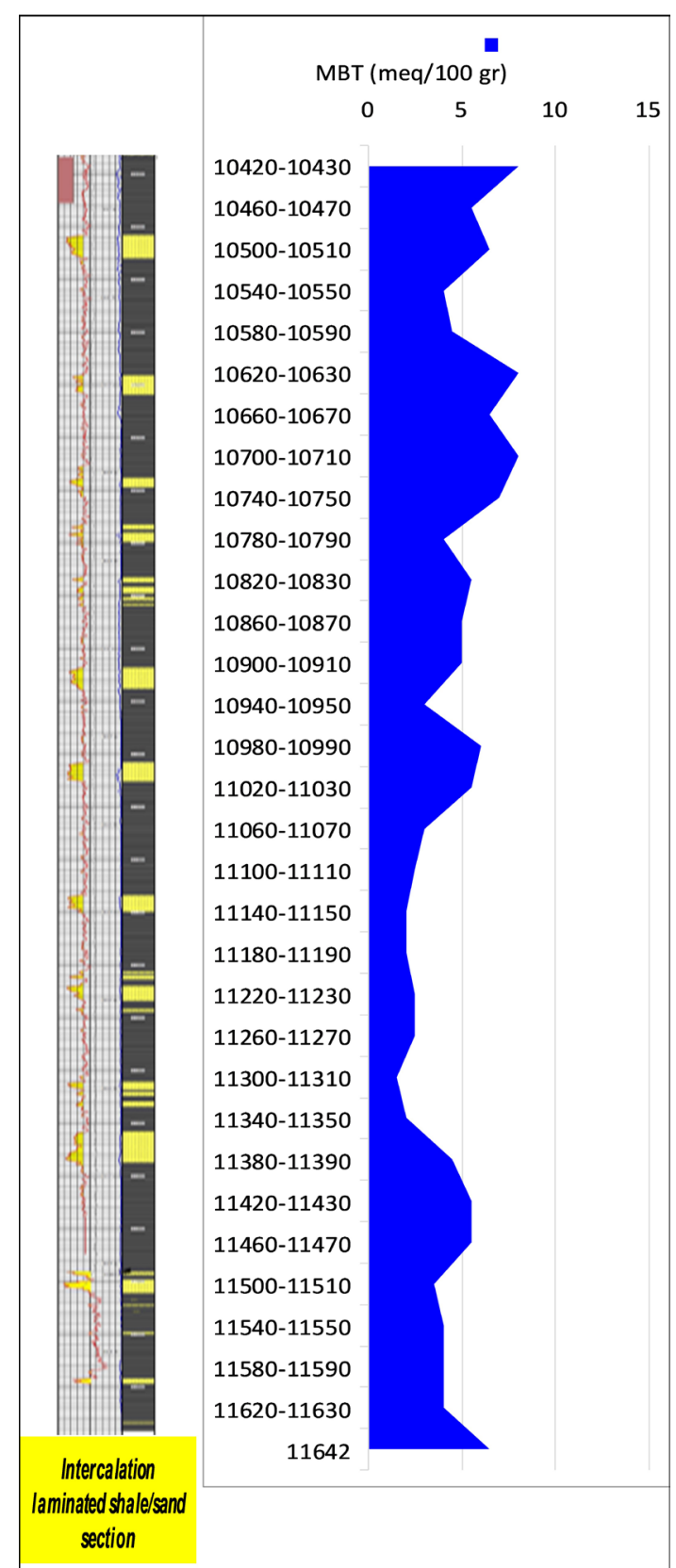

Figure 8. MBT Results vs. Depth interval of Brownshale Drill cuttings of Well BS-03.

of well BS-03, it can be integrated to determine a good sweetspot interval as a hydraulic fracking candidate. Figure 10 shows the integration of the results of mineralogy and TOC analysis of Brownshale drill cuttings.

From Figure 10 which is the correlation of depth ( $\mathrm{ft}$ ), mineral content, brittleness index, MBT, and TOC, that the Brownshle formation can be determined as a sweetspot fracable interval as a good hydraulic fracking candidate with the following criteria [13]:

1) TOC: 1475 wt $\%$ Avg (>1 wt\%)

2) The total thickness of the Brownshale formation: $1028 \mathrm{ft}(>100 \mathrm{ft})$.

3) Moderate clay content: $10.57 \%$ Avg $(<40 \%)$ 
4) Brittless index: $0.79 \operatorname{Avg}(>0.48)$

5) High Fracability: MBT: <3 cc meq/100gr (brittle), >3 cc meq/100gr (hard/less brittle).

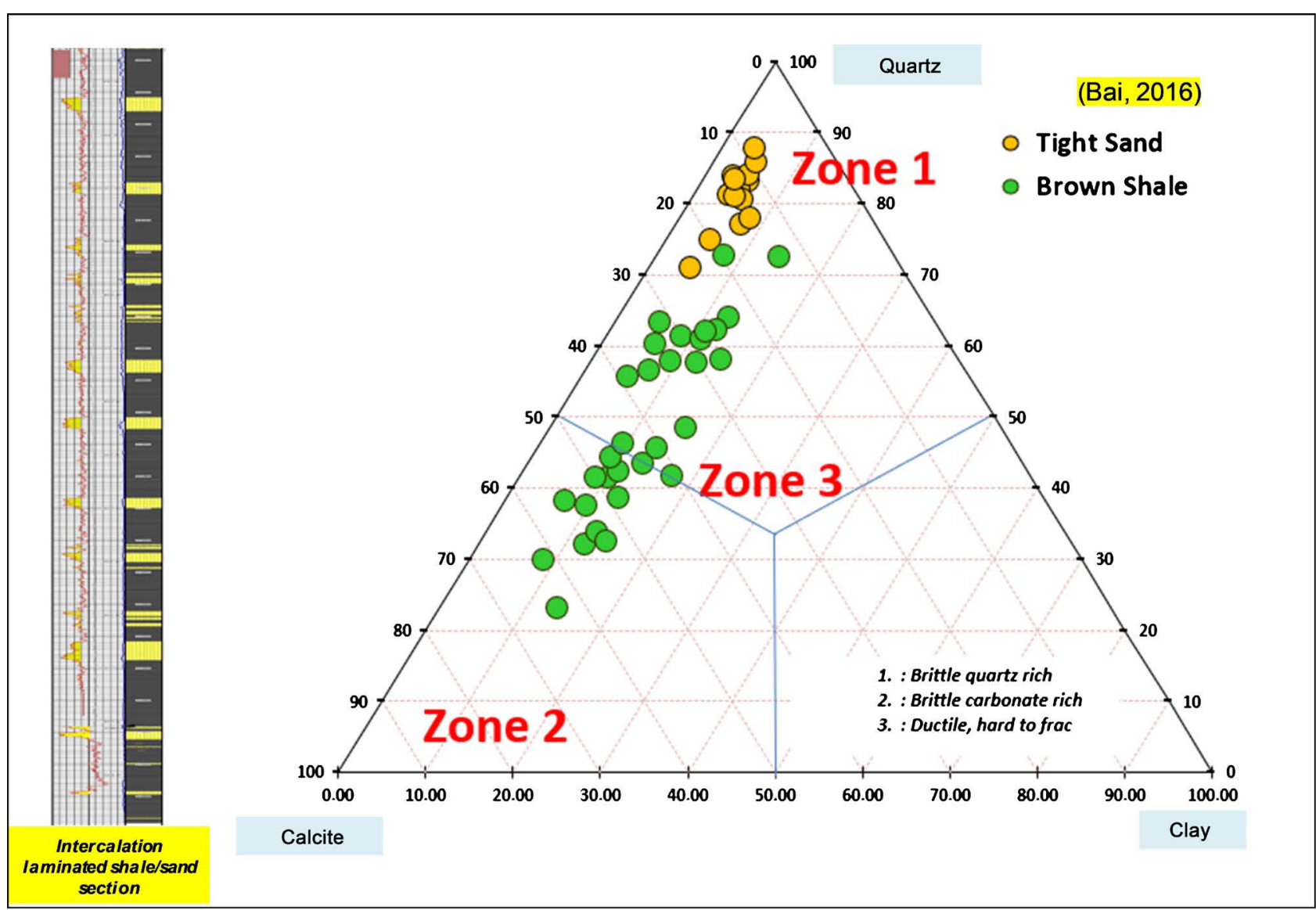

Figure 9. Plot Ternary Diagram of XRD analysis (bulk) results from drill cuttings of Brownshale formation of Well BS-03.

Table 3. The results of the TOC analysis of the Brownshale drill cuttings sample of Well BS-03.

\begin{tabular}{cccc}
\hline & Depth (feet) & Lithology & TOC (wt\%) \\
\hline 1 & $10,100-10,110$ & ylwsh gy, sli cal, Sst & 0.4 \\
2 & $10,500-10,510$ & gysh blk, sli cal, Clst & 2.46 \\
3 & $10,600-10,670$ & lt brnsh gy, sli cal, Sltst & 0.96 \\
4 & $10,820-10,830$ & olv blk, sli calc, Clst & 2.07 \\
5 & $10,980-10,990$ & gysh blk, non calc, Clst & 2.24 \\
6 & $11,100-11,110$ & brnsh gy, non calc, Clst & 1.64 \\
7 & $11,220-11,230$ & lt brnsh, calc, Sltst & 0.69 \\
8 & $11,380-11,390$ & lt gy, sli calc, Clst & 1.14 \\
9 & $11,500-11,510$ & dk gy, sli calc, Clst & 1.12 \\
10 & 11642 & med brn, calc, Clst & 2.02 \\
\hline
\end{tabular}

S1 = Free Hydrocarbons; Oil Production Index $=$ Transformation Ratio $=S 1 /(S 1+S 2) .{ }^{*}$ TOC content by Leco Analyzer. 


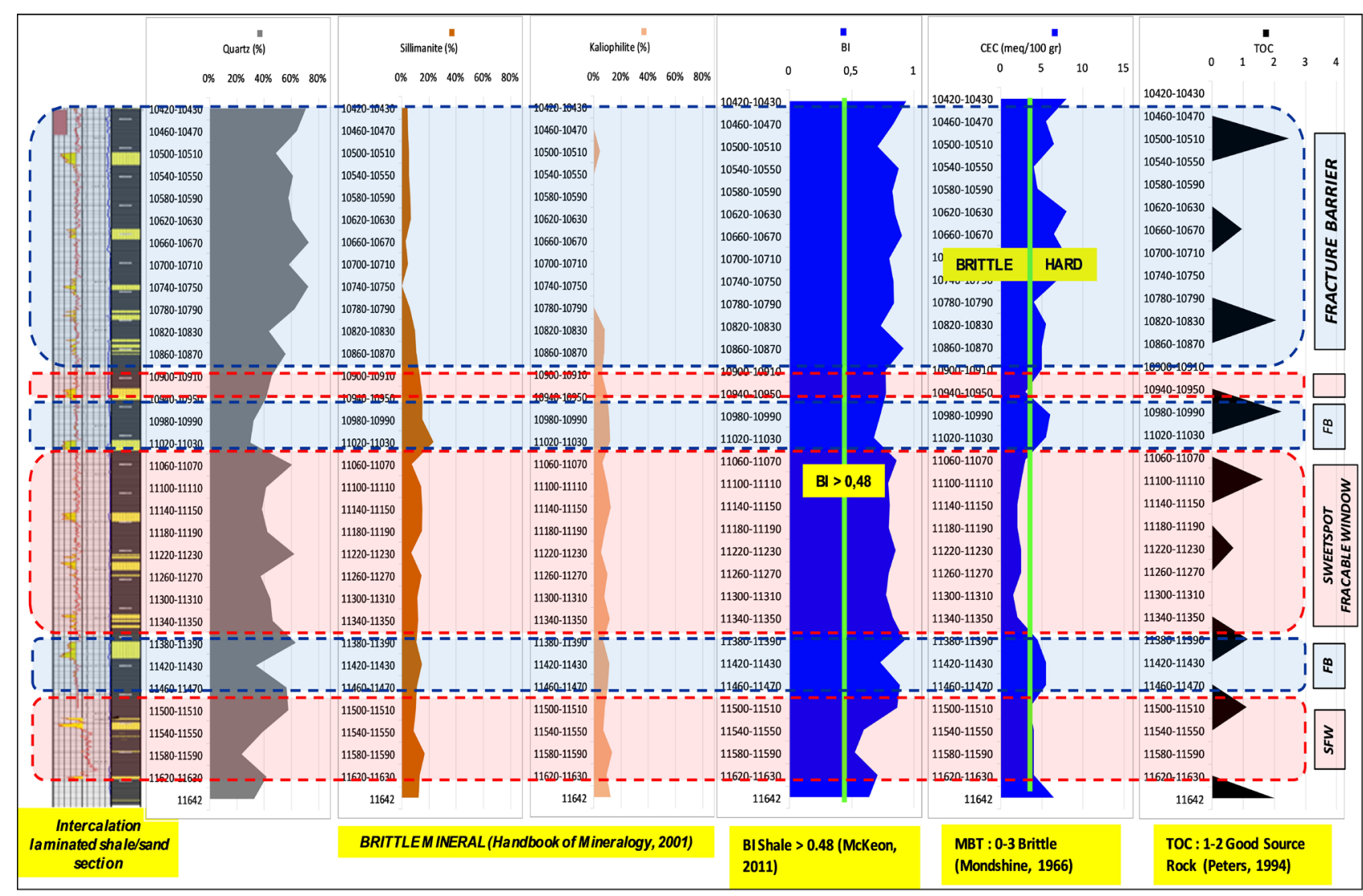

Figure 10. Integration of the results of mineralogy (XRD \& MBT) and TOC analysis of Brownshale drill cuttings of Well BS-03.

From the correlation in Figure 9, it can also be seen that at the bottom of the depth interval as a fracable sweetspot window, and at the upper depth interval of the Brownshale formation, it is believed to be a fracture barrier.

\section{Conclusions}

1) From the ternary diagram of XRD (bulk analysis) results of Brownshale drill cuttings of well BS-03, it shows that not all Brownshale formation intervals are easy to frac (high fracability).

2) TOC analysis results from Brownshale drill cuttings of well BS-03 varied between 0.40 - $2.46 \mathrm{wt} \%$ (1475 wt\% Avg); thus the Brownshale formation can be developed, and total thickness of the Brownshale formation is $1028 \mathrm{ft}(>100 \mathrm{ft}$ ), can be categorized as a very good thickness for horizontal drilling applied combined with multistage fracking.

3) From the XRD result of mineral content (bulk analysis) of Brownshale drill cuttings of well BS-03, there is an interesting phenomenon, i.e. the presence of sillimanite and kaliophilite minerals significantly starts at a depth of $10,780 \mathrm{ft}$ MD and below, where both minerals have tenacity: brittle.

4) From the results of the MBT analysis, it can be seen an interesting phenomenon, i.e. at a depth interval of about 10,780 ft the value of CEC drops below 3 meq/100 grams, and can be categorized as the brittle shale.

5) Referring to the presence of sillimanite and kaliophilite minerals, as well as 
low MBT values, then at intervals of $10,780 \mathrm{ft}$ below, it can be seen that at the bottom of the depth interval as a fracable sweetspot window, and at the upper depth interval of the Brownshale formation, it is believed to be a fracture barrier.

\section{Acknowledgements}

The authors thank to Malacca Strait EMP Group and CPP Block BOB PT. Bumi Siak Pusako-Pertamina Hulu for contributing data and permission for publication.

\section{Conflicts of Interest}

The authors declare no conflicts of interest regarding the publication of this paper.

\section{References}

[1] Bai, M. (2016) Why Are Brittleness and Fracability Not Equivalent in Designing Hydraulic Fracturing in Tight Shale Gas Reservoirs. Petroleum, 2, 1-19.

https://www.researchgate.net/publication/301693810

https://doi.org/10.1016/j.petlm.2016.01.001

[2] NN (2015) Indonesia-Shale Gas, KIGAM.

http://ccop.asia/uc/data/45/docs/1-Sim.pdf

[3] Breyer, J.A., et al. (2011) Predicting Fracability in Shale Reservoirs. Barnett Shale in the Fort Worth Basin, Texas, USA.

http://www.searchanddiscovery.com/pdfz/documents/2011/40783enderlin/ndx_end er-lin.pdf.html

[4] Jarzyna, J.A., et al. (2017) Shale Gas in Poland. Advances in Natural Gas Emerging Technologies.

https://www.intechopen.com/books/advances-in-natural-gas-emerging-technologie s/shale-gas-in-poland

[5] Heidrick, T.L. and Aulia, K. (1993) A Structural and Tectonic Model of the Coastal Plains Block-Central Sumatra Basin. 22nd Annual Convention Proceedings, 1, 285-317.

http://archives.datapages.com/data/ipa/data/022/022001/285_ipa022a0285.htm

[6] Bragg, W.H. and Bragg, W.L. (2001) Handbook of Mineralogy. https://royalsocietypublishing.org/doi/10.1098/rspa.1913.0040

[7] Perez, R. and Marfurt, K. (2013) Calibration of Brittleness to Elastic Rock Properties via Mineralogy Logs in Unconventional Reservoirs. University of Oklahoma, Norman, Oklahoma.

http://www.searchanddiscovery.com/documents/2013/41237perez/ndx_perez.pdf

[8] Jarvie, D.M. (2007) Unconventional Shale Gas System: The Mississippian Barnet Shale of North-Central Texas as One mMdel for Thermogenic Shale Gas Assessment. AAPG Bulletin. https://doi.org/10.1306/12190606068

[9] Rickman, R., et al. (2008) A Practical Use of Shale Petrophysics for Stimulation Design Optimization: All Shale Plays Are Not Clones of the Barnett Shale. Society of Petroleum Engineers, Colorado. https://doi.org/10.2118/115258-MS

[10] Li, J.B., Lu, S.F. and Chen, G.H. (2015) Fracability Evaluation of the Unconventional Mud-Shale Reservoir. University of Petroleum (East China), Shandong. https://doi.org/10.1111/1755-6724.12305_6 
[11] Babajide, A., et al. (2016) Effect of Temperature and Pressure on Shale Cuttings Dispersion. In SPE-184310-MS. https://doi.org/10.2118/184310-MS

[12] Peters, K.E. and Casa, M.R. (1994) Applied Source Rock Geochemistry. In: Magoon L.B. and Dow W.G., Eds., The Petroleum System: From Source to Trap, American Association of Petroleum Geologists, Tulsa, 93-120.

https://www.scirp.org/(S(lz5mqp453edsnp55rrgjct55))/reference/ReferencesPapers. aspx?ReferenceID $=1794434$

[13] McKeon (2011) Horizontal Fracturing in Shale Plays. Halliburton.

https://www.slideserve.com/eshana/horizontal-fracturing-in-shale-plays-matt-mcke on

[14] Buntoro, A., et al. (2018) Validation of Shale Brittleness Index Calculation from Wireline Log of Well BETRO-001 by Using XRD Test Results and Uniaxial Test as Parameters for Determining Potential of Shale Hydrocarbon. Brown Shale of Pematang Group Formation, Central Sumatra.

https://doi.org/10.1088/1755-1315/212/1/012069 